\title{
Will Workers Want To Be Laid Off?
}

\author{
YiLi Chien, Research Officer and Economist \\ Julie Bennett, Research Associate
}

$\mathrm{n}$ response to the rapid decline of economic activity caused by the COVID-19 pandemic, Congress passed the CARES Act to provide economic relief on many fronts. With respect to unemployment insurance (UI), CARES provides an additional $\$ 600$ per week in unemployment benefits for all eligible UI claimants. This extra $\$ 600$ dollars is not a trivial amount, especially compared with the ordinary weekly UI benefit. According to the data from the U.S. Department of Labor, in the fourth quarter of 2019, the average weekly UI benefit ranged from $\$ 213$ (Mississippi) to $\$ 515$ (Massachusetts) across U.S. states. The national average weekly amount is $\$ 378 .{ }^{1}$ With this supplemental UI benefit, some individuals may receive more in UI benefit payments than they would have received in wages if they were still employed. Taking the national average UI benefit of $\$ 378$ as the baseline, the new amount of the average UI check should be around $\$ 978(\$ 600+\$ 378)$. This amount exceeds the average weekly paycheck for many industries hit the hardest by COVID-19, as reported in the table. ${ }^{2}$

\section{The short-term income benefits from expanded unemployment insurance are unlikely to outweigh the long-term benefits of working.}

Will the higher-than-usual UI benefits cause problems? Some have expressed concern that the extra benefit could create an incentive to lay off employees. ${ }^{3}$ Others have pointed out that it could also slow the return of workers to their jobs once employment becomes available again. ${ }^{4}$ These concerns are legitimate, and no one knows how the situation will play out. However, in our view, several considerations may help alleviate concerns regarding the higherthan-usual UI benefits.

First, the extra $\$ 600$ UI benefit lasts only four months (until July 31,2020 ), ${ }^{5}$ which is a relatively short period of time. In the current crisis, many unemployed workers are temporarily laid off or furloughed; hence, recalls are expected when normal business activity can resume. Once recalled, will workers decline returning to work in favor of

\section{Average Weekly Earnings by Selected Industry Sector, March 2020}

\begin{tabular}{lr}
\hline Total private & $\$ 978.80$ \\
\hline Construction & $\$ 1,224.22$ \\
\hline Total private service-providing & $\$ 936.87$ \\
\hline Retail trade & $\$ 626.03$ \\
\hline Transportation and warehousing & $\$ 964.22$ \\
\hline Education and health services & $\$ 917.91$ \\
\hline Leisure and hospitality & $\$ 410.65$
\end{tabular}

SOURCE: Bureau of Labor Statistics.

receiving UI benefits? If so, then recovery could be prolonged. However, the long-term benefit of being employed far exceeds the short-term UI benefit, as after July 31 UI benefits will no longer contain the extra $\$ 600$. If unemployed workers do decline the recall and wait until August to search for a new job, they may run into significant challenges, as job search costs are nontrivial and there is no guarantee of finding another job. Thus, it is likely that workers will return to their jobs once recalled.

Second, many workers laid off in the wake of COVID-19 have lost not only their wages but also their employer health insurance, which could be a major disadvantage. Therefore, workers will likely be eager to return to work to regain this benefit.

Finally, the academic literature has pointed out that UI benefits in general do not provide a strong disincentive for job searching (see Fuller et al., 2015). Instead, the major problem of UI benefits is the fraudulent collection of these benefits. ${ }^{6}$

In light of the higher-than-usual UI benefits, it is also possible that some essential-business workers could feel they are in an unfair situation. Some of these workers are paid less than the extended UI benefits, and they now face hazardous working conditions due to the COVID-19 pandemic. It is unclear whether the modification of UI eligibility rules under the CARES Act would allow them to quit their jobs and claim UI. The new requirements stipulate 


\section{ECONOMIC Synopses}

that an individual is eligible for UI if "the individual has to quit his or her job as a direct result of COVID-19."7 This could mean quitting in order to take care of someone who is ill or to take care of or homeschool their children (as most schools and childcare facilities are now closed). It is unclear whether someone could quit due to concerns about being infected while on the job and still receive UI benefits. ${ }^{8}$

Will some workers want to be laid off because of the extended UI benefit? The answer surely varies person to person. However, we argue that the short-term monetary benefits brought by the UI extension are unlikely to outweigh the long-term benefits of working.

\section{Notes}

1 These statistics are reported by the U.S. Department of Labor and can be found at https://oui.doleta.gov/unemploy/data summary/SummaryTables.pdf.

2 This fact has also been reported by the media. For example, see lacurci, G. "Coronavirus Bill Will Create 'Devastating' Incentive To Lay Off Employees, Critics Say." CNBC, updated March 27, 2020; https://www.cnbc.com/2020/03/25/coronavirus-bill-boosts-unemployment-benefits-covers-gig-workers.html.

3 lacurci, 2020. See footnote 2.

${ }^{4}$ LaJoie, T. "Evaluating the Trade-offs of Unemployment Compensation Changes in the CARES Act." Tax Foundation, March 27, 2020; https://taxfoundation.org/unemployment-compensation-changes-cares-act/.

5 lacurci, G. "Do You Have Questions about Unemployment Benefits? Here's What You Need to Know." CNBC, updated April 12, 2020; https://www.cnbc.com/2020/04/09/heres-what-you-need-to-know-about-unemployment-benefits.html.

${ }^{6}$ The authors thank B. Ravikumar for pointing this out.

7 See https://www.congress.gov/bill/116th-congress/house-bill/748/text\#H1C588D1724DE4D009850DE202C8FFF62.

8 LaJoie, 2020. See footnote 4.

\section{Reference}

Fuller, D.L.; Ravikumar, B. and Zhang, Y. "Unemployment Insurance Fraud and Optimal Monitoring." American Economic Journal: Macroeconomics, 2015, 7(2), pp. 249-90. 